\title{
URBAN ARCHAEOLOGY IN THE ACTIVITIES OF THE MANAGEMENT OF RESEARCH ON THE BEGINNINGS OF THE POLISH STATE (1949-1953)
}

\author{
Adrianna $S Z C Z E R B A$ \\ Institut of Archaeology, University of Lodz, \\ G. Narutowicza Str., 65, 91-137, Lodz, Poland, \\ e-mail: Adrianna.Szczerba@uni.lodz.pl
}

The Management of Research on the Beginnings of the Polish State was established to carry out extensive, interdisciplinary research on the genesis and functioning of the state of the first Piasts, which was undertaken in connection with the need to celebrate the 1000-th anniversary of the Polish state and its baptism. In 1949-1953, Early Medieval archaeological sites were examined in 31 cities. The most attention was devoted to strongholds with Piast records (Gdańsk, Gniezno, Giecz, Poznań, Kruszwica, Kalisz, Tum pod Łęczycą, Błonie, Bródno, Wrocław, Opole, Niemcza, Cieszyn, and Wiślica). Most of them are located in the medieval centers of modern cities. In this situation the natural order of things was to link the problems of Early Medieval castles with the problems of the beginnings of Polish cities. Early Medieval sites in Poland, usually with a complicated stratigraphy, especially in the case of cities or strongholds, are the most difficult to excavate. Meanwhile, at that time only limited experience of excavation work at multi-layer sites prior to World War II was available - as a consequence, research methods for larger settlement complexes were developed on an ongoing basis, in the course of the research itself. Thus, the Millennium program has become a kind of testing ground in the field of urban archaeology in Poland.

Key word: history of Polish archaeology, Management of Research on the Beginnings of the Polish State, millennium archaeology, urban archaeology.

Right after the end of the World War II, a reflection appeared in the historical environment on the upcoming thousand-year anniversary of the Polish state and its baptism, i.e. the Polish Millennium (1966). Although the anniversary was understood differently by the Church and the State [Noszczak, 2002], the need for proper preparation of the celebrations lay in the foundations of the establishment of the Management of Research on the Beginnings of the Polish State in 1948-1949 [Szczerba, 2017]. It was a specialized structure, gathering researchers of various specialties: archaeologists, historians, art and architecture historians, ethnographers and representatives of natural sciences (anthropologists, geologists, geographers, botanists, etc.), whose task, implemented as part of interdisciplinary cooperation and a broadly developed archaeological research program, was to gather as much information as possible about the origin and functioning of the state of First Piast dynasty. Meanwhile, for less scientific reasons, great emphasis was placed on "proving the Polish and Slavic character of the western and northern lands" (joined with the country by the decision of the Big Three at peace conferences in Yalta and Potsdam), which made archaeology and history a peculiar element of the state propaganda those days. It should be noted, however, that the political conditions of archaeological research did not deprive these activities of scientifically honest substance. There is no doubt, however, that the entire Polish historical environment was faced with very difficult substantive and organizational problems during the millennium research.

The spectrum of the research program on the beginnings of the Polish state, which has no precedents in the history of Polish and European archaeology, was impressive if we consider that at the same time excavations took place at several dozen archaeological sites from the early Middle Ages (castles, places of worship, rural settlements, cemeteries, etc.). In 1948, before the Management of the Beginnings of the Polish State was established, they included archaeological sites in 11 cities: 
Biskupin, Gdańsk, Gniezno, Kraków - Wawel, Kruszwica, Łęczyca, Opole, Ostrów Lednicki, Poznań Ostrów Tumski, Sobótka - the church of St. Jacob, Szczecin. The following year their number increased to 25 - 14 towns were added to the list: Bródno Stare, Cieszyn, Giecz, Inowłódz, Lutomiersk, Poznań - Góra Przemysła, Błonie, Trzemeszno, Kraków - Tyniec, Ślęża, so-called Wały Śląskie, Warszawa - Zamek Królewski, Wiślica, Wrocław - Ostrów Tumski. In 1950, excavations began in Igołomia, Kalisz, Niemcza and Strzelno. From 1952, so-called Grody Czerwieńskie were tried to be found (research was carried out in Gródek Nadbużny and Czermno nad Huczwą). In total, in the years 1948-1953, i.e. under the name of the Management of the Beginnings of the Polish State, archaeological work was carried out at archaeological sites in 31 cities. By the end of the research program on the beginnings of the Polish state, however, the number of archaeological sites increased to over 50 (fig.1). In parallel with the field work, extensive studies were conducted on written sources on the early medieval history of the Polish lands from various cultural circles and from different parts of Europe. Nevertheless, particular emphasis was put on archaeological research, since there were very few sources written for the early Middle Ages. Meanwhile, archaeology still had inexhaustible opportunities to gather new data illustrating the life of our ancestors in the Piast and Pre-Piast era. However, research had to be hurried before the progressive housing hinders the establishment of excavations. The districts of cities such as Gdańsk, Szczecin, Wrocław, Poznań and Warszawa, which were in ruins, have made it possible to carry out archaeological works (fig. 2, 3, 4). In addition to the need to study cities destroyed by war, it was postulated to continue the excavations started before the war in the area of leading centers of the "Polan State" in Greater Poland (Gniezno, Poznań, Ostrów Lednicki, Kruszwica, Giecz). The problem of developing a broad research front on numerous earlymedieval strongholds preserved in Poland was also raised. And finally, the specificity of the "millennium period" research has become work on the remains of early Romanesque and Romanesque architecture, facilitated by the war devastation of many important architectural monuments, hiding inside the remains of the oldest monumental buildings in Poland. It can be said without exaggeration that only excavations of the "millennium period" revealed the richness of architectural implementations associated with the beginnings of Polish statehood. Nevertheless, the widest research program took place in the area of the strongholds with Piast records (Gdańsk, Gniezno, Giecz, Poznań, Kruszwica, Kalisz, Tum pod Łęczycą, Błonie, Bródno, Wrocław, Opole, Niemcza, Cieszyn, Wiślica). Most of them are located in the medieval centers of modern cities, in this situation the natural order of things was to link the problems of early medieval castles with the problems of the beginnings of Polish cities. It is also worth mentioning that already in this period studies of microregional settlement complexes were initiated. They were undertaken more or less consistently around some stationary researched strongholds (e.g. Poznań, Giecz, Kruszwica). Unfortunately, with the exception of W. Hensel's publication about Poznań [Hensel, 1953], adding to the initial stage of this type of work, the rest were never completed. However, the reduced program of microregional research, in the form of at least archaeological penetration of the nearest facilities of stationary examined objects, has since become the binding rule.

Focusing on the negative sides of the millennium action, first of all, one should pay attention to the general methodical and methodological underdevelopment of Polish archaeology at the time of undertaking research on the beginnings of the Polish state. Early medieval sites in Poland, usually with a complicated stratigraphy, especially in the case of cities or strongholds, are the most difficult to excavate. Meanwhile, at that time only limited experience of excavation work at multi-layer sites prior to World War II was available - as a consequence, research methods for larger settlement complexes were developed on an ongoing basis, in the course of the research itself [Hołubowicz, 1948; Hensel, 1949a; Jażdżewski, 1948-1949; Kóčka, Ostrowska, 1954; Żurowski, 1947, 1948, 1951]. Therefore, there was usually a deliberately outlined spatial program of research on individual objects (especially in cities where the forms of former settlements or their fortifications were completely blurred).

The framework of this article does not allow a detailed discussion of the achievements of the Management of Research on the Beginnings of the Polish State in the field of urban archaeology. 
However, to present the specifics of these studies to a small extent, I will use the example of Ostrów Tumski in Poznań.

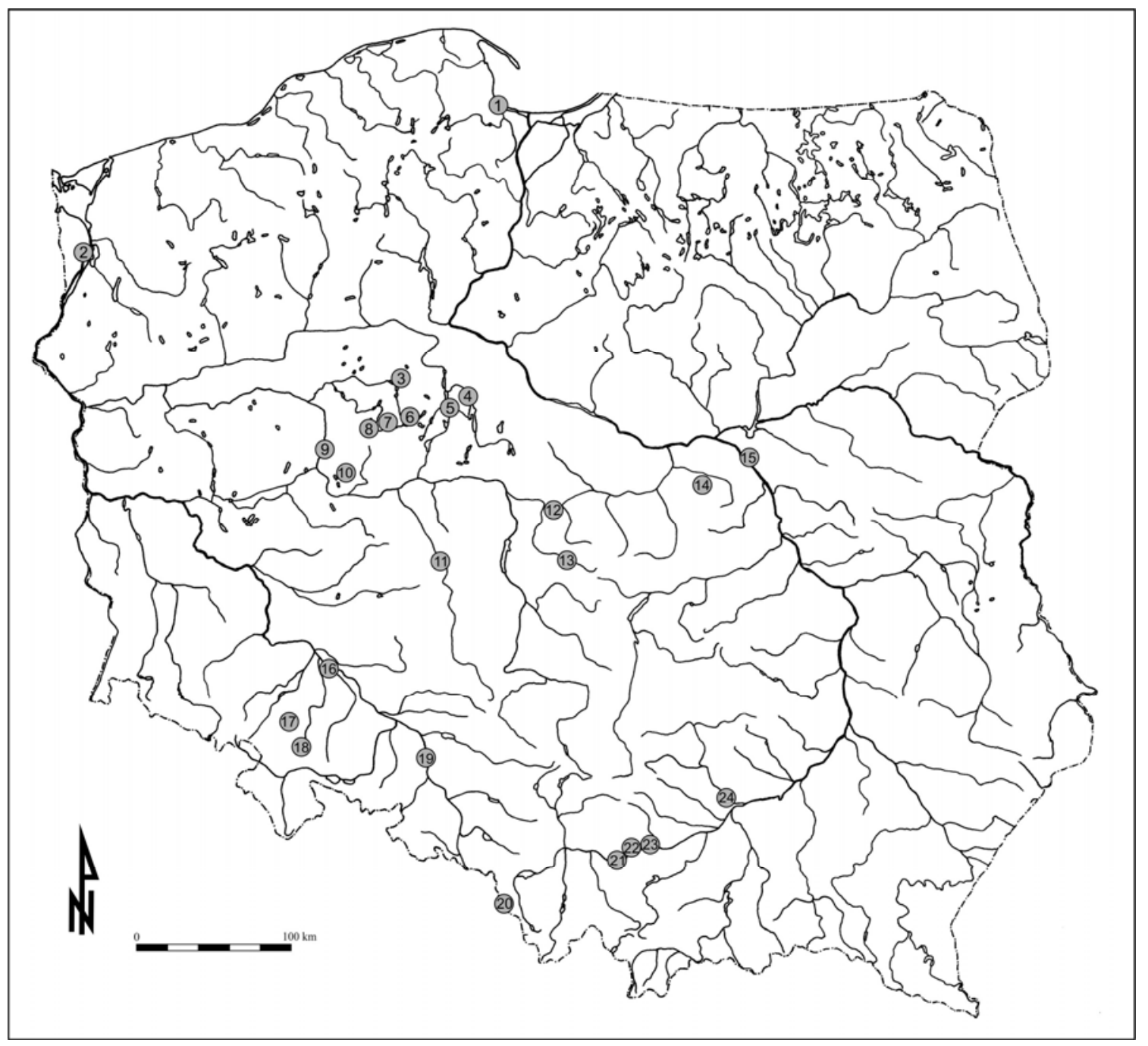

Fig. 1. Archaeological sites studied in Poland by the Management of Research on the Beginnings of the Polish State (1949-1953): 1 - Gdańska, 2- Szczecin, 3- Biskupin, 4- Kruszwica, 5- Strzelni, 6- Trzemeszno, 7- Gniezno, 8- Ostrów Lednicki, 9- Poznań, 10- Giecz, 11 - Kalisz, 12 - Łęczyca, 13- Lutomiersk, 14- Błonie, 15- Bródno, 16-Wrocław, 17-Ślęża, 18- Niemcza, 19-Opole, 20-Cieszyn, 21- Tyniec, 22 - Kraków, 23- Nowa Huta, 24-Wiślica. In addition, in 1949 - 1951 the Management conducted excavations at the Royal Castle in Warsaw, at the so-called Silesian embankemnts (near Oder river), in Sobótka (church of St. Jacob) and in 1952 began searching for so-called Grody Czerwieńskie. Authors of map: J. Gołębiowska, A. Szczerba

Рис. 1. Археологічні пам'ятки, вивчені в Польщі Управлінням досліджень про початки Польської держави (1949-1953): 1 - Гданськ, 2 - Щецин, 3 - Біскупін, 4- Крушвиця, 5 - Стшельні, 6 - Тшемешно, 7 - Гнєзно, 8 - Острув Ледницький, 9- Познань, 10 - Геч, 11 - Каліш, 12 - Ленчиця, 13 - Лютомерськ, 14 - Блонє, 15 - Брудно, 16- Вроцлав, 17 - Сьленжа, 18 - Немча, 19 - Ополе, 20 - Цешин, 21 - Тинець, 22 - Краков, 23- Нова Гута, 24- Віслиця. Крім того, у 1949-1951 роках Керівництво проводило розкопки в Королівському замку у Варшаві, на т. зв. Сілезьких дамбах (біля річки Одра), у Собутці (церква святого Якова) і в 1952 р. почали шукати так звані Червенські міста. Автори карти: Й. Голембйовська, А. Щерба 
Planned archaeological research in Ostrów Tumski in Poznań began in 1938. The intention to undertake them - as W. Hensel wrote at the time - resulted from the discussion of historians regarding the capital function of the Poznan castle in the early Piast state, as well as promising prewar discoveries in Opole, Santok, Wolnie, Kłecko and Gniezno [Hensel, 1959, p. 7]. Research team under the guidance of prof. J. Kostrzewski, MA W. Kóčka and MA W. Hensel were able to confirm the location of the castle beyond doubt.

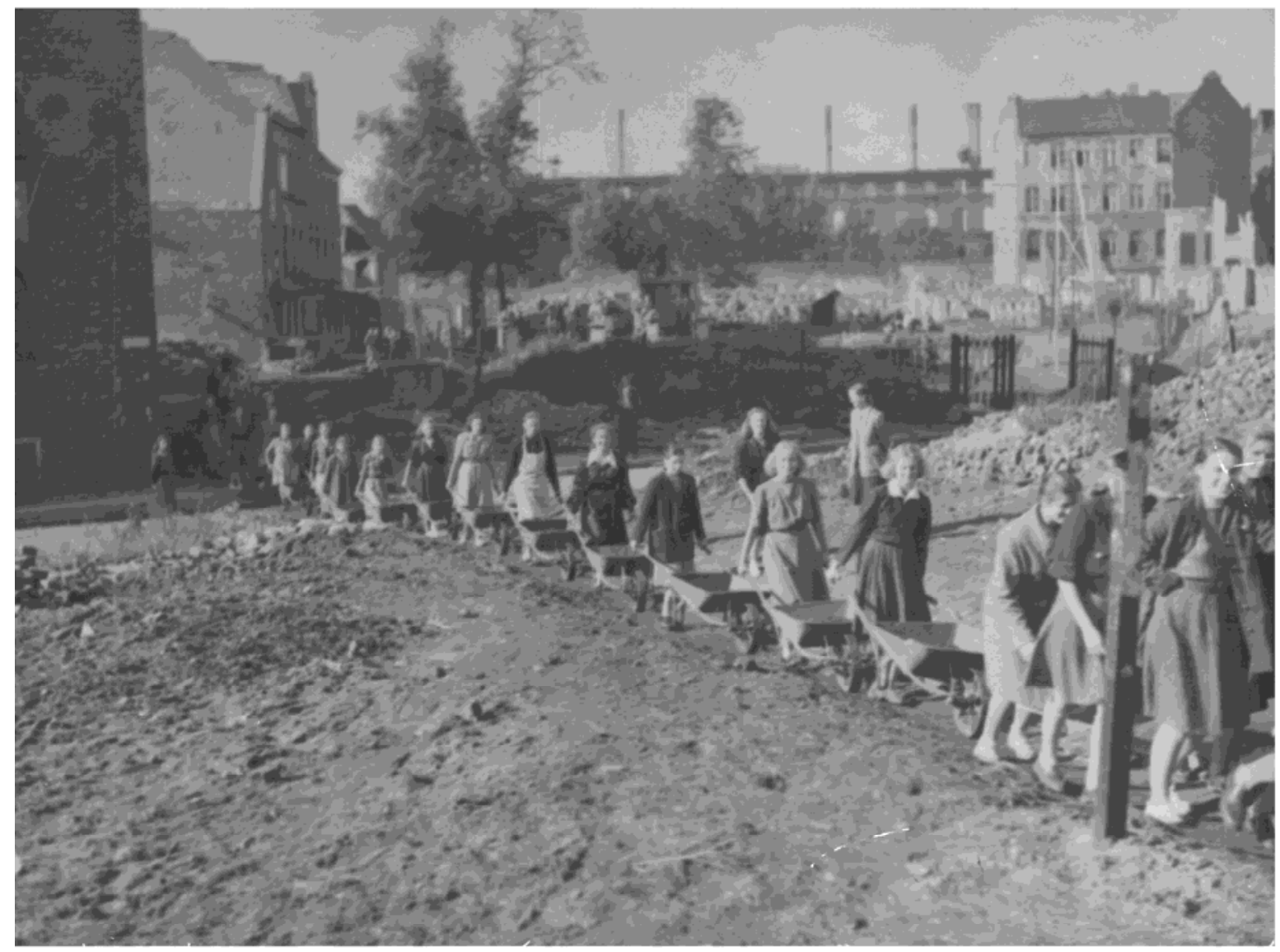

Fig. 2. Archaeological research in Szczecin. From the collections of IAiE PAN in Warsaw Рис. 2. Археологічні дослідження в Щецині. 3 колекцій IAiE ПАН у Варшаві

"From the former Piast stronghold in Poznań, which together with Gniezno and Giecz belonged to the most populous centers of the Chrobry State - commented J. Kostrzewski's research there were not the slightest traces on the surface of the earth, and most interestingly, no historical mentions about the place to be preserved where it used to be once. Therefore, excavation works aimed at discovering the oldest Poznań stronghold, started on behalf of the Prehistoric Institute of the University of Poznań in May same year in Ostrów Tumski, under the leadership of Mr. Witold Hensel, they were directed to the area between the Cathedral and the Church of the Virgin Mary only on the grounds that the castle could not be located far from the cathedral. This assumption was fully confirmed in the course of the research, as we came across a depth of two and a half meters below today's Cathedral Square level on a well-preserved wooden and stone structure of the embankment, surrounding the castle, crossing the square from north to south and bending on both ends towards the former Warta channel. The shape of the embankment shows that the cathedral was already similarly as in Gniezno at the beginning of the 11th century - outside the stronghold, on the outskirts. The uncovered embankment can be dated (...) for around 1000 or even for the second half of the 10th 
century. It therefore dates back to the time of Chrobry or even Mieszko I, and was destroyed in the first half of the 11th century, apparently in connection with the riots after death of Mieszko II" [Kostrzewski, 1938, p. 18].

Excavation works were continued in 1939 on the square in front of the church of St. Mary (excavation at the street leading to the cathedral) at Lubrańskiego (currently Ks. I. Posadzkiego street) and at the Theological Seminary at Wieżowa (Zagórze). Unfortunately, the outbreak of World War II interrupted the promising search, which made it possible to recognize the embankments of the Poznań castle in several places. They were resumed in 1946: in the garden of property 10 Ostrów Tumski, adjacent to the church of the Blessed Virgin Mary from the north [Żak, 1959], as well as inside the cathedral, destroyed by fire on February 15, 1945. The area adjacent to the Blessed Virgin Mary church from the north (property at 10 Ostrów Tumski Street) attracted the attention of archaeologists since the research of the cathedral square in 1938, when huge defensive walls were discovered. These fortifications, however, surrounded not the cathedral, but the area western from it. What required such perfect defense? Was there an object more important than the cathedral? W. Hensel put forward the first theory - as it turned out years later - the right one. He claimed that behind the rampart there was a "castle" of the first Polish rulers, but archaeological works around the church of the Blessed Virgin Mary in 1939 and in 1946 did not bring the expected results. It was not until the research resumed in 1999 thanks to prof. Hanna Kócka-Krenz revealed the remains of a palatium built by Mieszko I in the second half of the 10th century (the palace chapel was also discovered in 2009) [Kócka-Krenz, 2001; 2004; 2005].

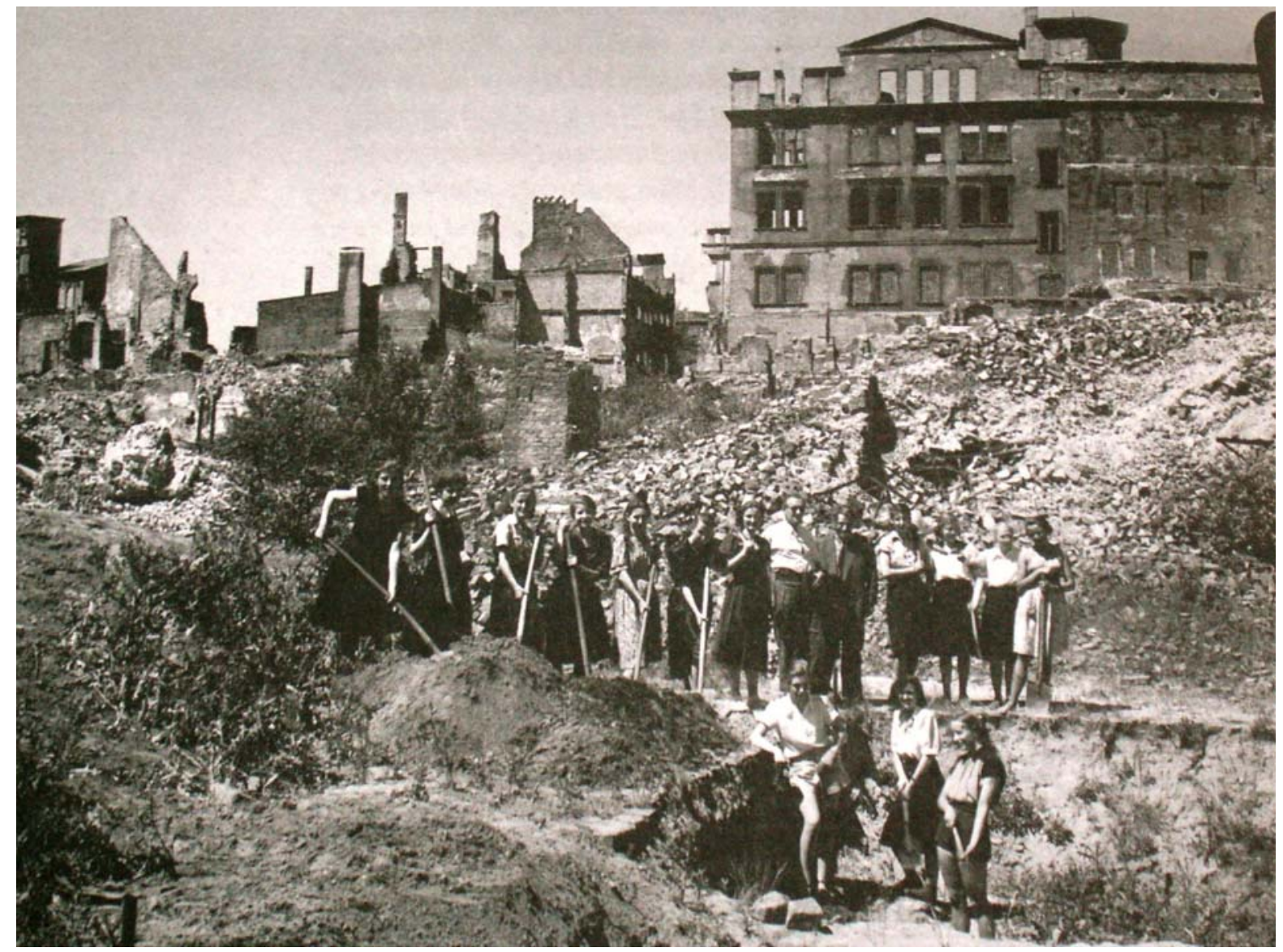

Fig. 3. Archaeological research in Gdańsk. From the collections of Museum of Archaeology in Gdańsk Рис. 3. Археологічні дослідження в Гданську. 3 колекцій Музею археології у Гданську 
In 1948, on behalf of the Supreme Directorate of Museums and Monuments Protection, in cooperation with the Institute of Slavic Antiquities of the University of Poznan, archaeological research was carried out in the garden of the property at 11 Ostrów Tumski [Wiślański, 1960; Hensel, 1949]. The head of the excavation was Dr. Witold Hensel, deputies: MA Leon Jan Łuka and Aleksandra Cofta, interns: Jacek Slaski and Jan Żak. The following year, excavations were suspended due to the need to develop found pre-war materials. In 1950-1953, already on behalf of KBnPPP, archaeological research was carried out on the property at 13 Ostrów Tumski and in the garden of the Seminary at Wieżowa 2-4 (Zagórze) [Hensel, 1952; Dymaczewski, 1961; Niesiłowska, Perzyńska, Żak, 1960], in 1953 (and in the following year) on the property at 17 Ostrów Tumski [Dymaczewski, Leciejwicz 1955; Malinowska, 1960].

The main purpose of excavations on the property at 13 Ostrów Tumski, which under the scientific direction of prof. W. Hensel was led by: A. Cofta and J. Żak was to determine the further course of the embankments discovered in 1948. Archaeological works at Wieżowa 2-4, hwever, were supposed to provide information about the borough - its range, layout and functions, as well as connections with the stronghold and economic facilities (a craft and market settlement was discovered at that time). Here, the deputy for prof. W. Hensel was firstly tragically deceased in 1951 by J. Slaski, then MA Edward Dąbrowski, and after his departure for archaeological research to Gródek Nadbużny - Lech Leciejewicz. The issue of knowing the layout of the borough's development was also served by works at the stand at the property 17. Ostrów Tumski. They lasted for two seasons: in 1953, as part of the Management of Research on the Beginnings of the Polish State's activities, they were led by MA E. Dąbrowski, in the following year, already under the supervision of Institute of History of Cultural Science of Polish Academy of Science (IHKM PAN), MA Aleksander Dymaczewski and MA J. Żak (the supervision to whole project was led by Prof. W. Hensel).

Archaeological works in Ostrów Tumski were part of a larger research program on the problem of the formation of an urban center in Poznan. This program, in addition to researches on the Poznań castle and explaining its role during the formation of the Polish state - which was a priority - also involved developing the issue of the genesis and development of an early-feudal city of Poznan on its river left-bank. Heading from the ends of the city to its early medieval center, it was planned to collect data on the number and forms of settlement in Poznań, starting from the Roman period. Research in this direction began in 1950 at Mińska 3 (currently Krańcowa 77) - in the interwar period a house and probably a tomb from the late Roman period were discovered there (end of III beginning of IV century $\mathrm{AD}$ ) - but for financial reasons they were not continued. Other positions selected at the time, such as the market settlement at the nonexistent church of St. Gotthard or St. Wojciech, where a modern defensive center was supposed to exist, for the stronghold in Ostrów Tumski [Münch, 1946], also due to financial restrictions, they were only subjected to research by the Poznan Archaeological Station - Castle IHKM PAN (headed by W. Hensel), which continued archaeological work in Ostrów Tumski at 17 Ostrów Tumski (1954), in the cathedral square (1958), at Wieżowa 2 (1960-1962) and in the Archbishop's Garden (1960-1961). However, most of the archaeological research planned in 1950 in the left-bank Poznan was carried out many years later on the occasion of construction investments, but only as a part of the supervision [Kaczmarek, 2008].

As already mentioned, the post-war archaeological work in Ostrów Tumski lasted intermittently from 1946 to 1962, including from 1950 to 1953 as part of the Management of Research on the Beginnings of the Polish State's activity, leaving from this campaign not only excellent documentation, but also all published materials, which was undoubtedly due to W. Hensla, who supervised the development of the acquired sources, and also proposed a unified manner of their presentation. He commented on his purpose as follows: "It's all about establishing rules that, on the one hand, allow the furthest possible selection of repetitive, serial material, and on the other hand, ensure the most objective representation of the extracted sources in their full context' [Hensel, 1959, p. 9]. However, the intended objectivity of the publication of moving materials in the stratigraphic system, according to subsequent research excavations, resulted in the lack of spatial and functional characteristics of discovered settlement complexes in these positions. Also formulated during the 
millennium research (largely based on the results of research from 1938-1939, 1946-1953), the concept of the form and function of the Poznan castle did not receive the final monograph summarizing the partial theses arising in the course of the research, but the basic approach to this problem can be read from successively published scientific and popular science studies [Hensel, 1953; 1958, 1960; Hensel, Żak, 1964].

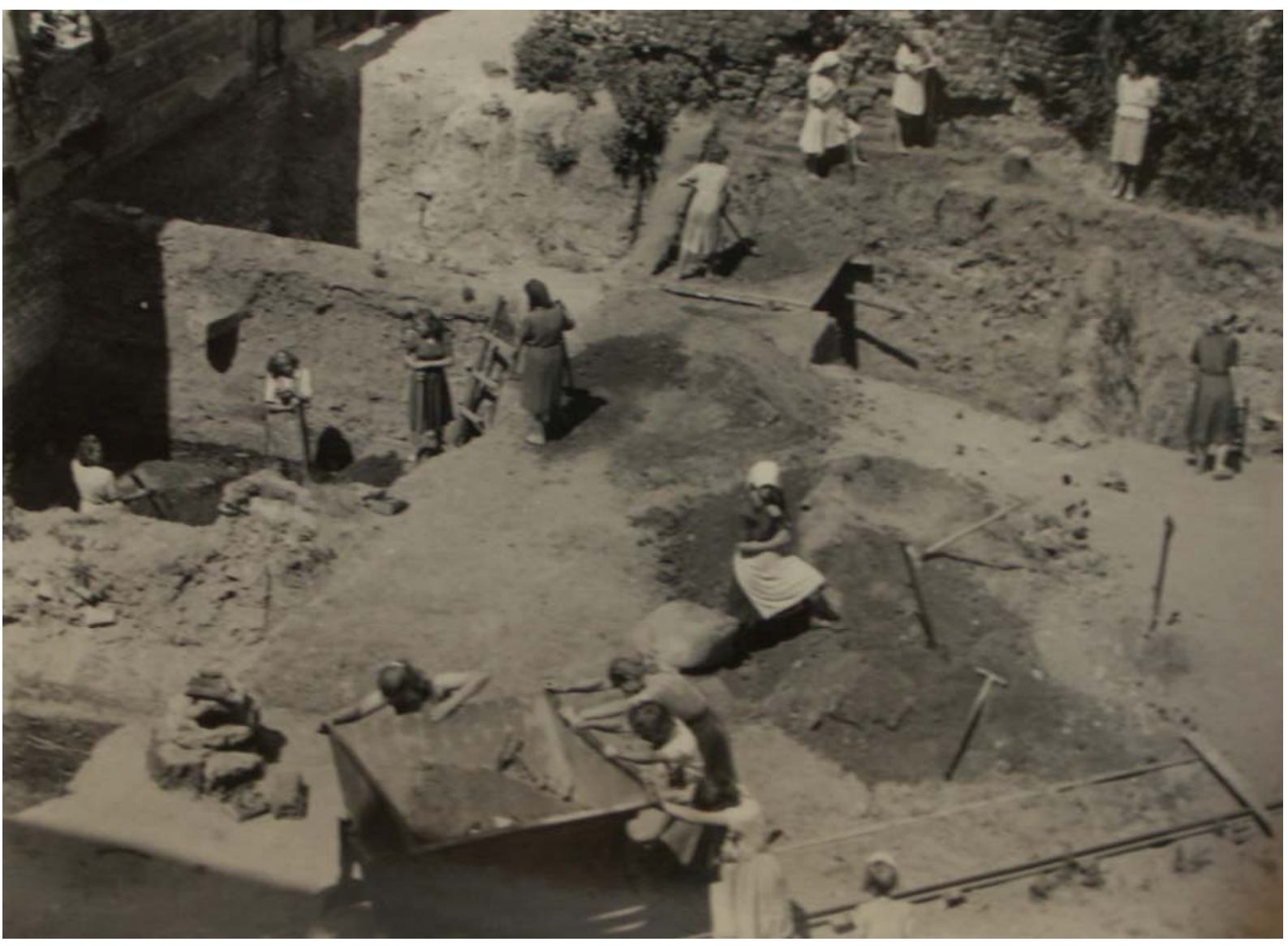

Fig. 4. Archaeological research in Ostrów Tumski in Wrocław. From the collections of IAiE PAN in Wrocław Рис. 4. Археологічні дослідження на Оструві Тумський у Вроцлаві. 3 колекцій IAiE ПАН у Вроцлаві

Difficulties during attempts to fully publish and exploit rich and diverse materials from multilayer workplaces were a common problem at the time. As it has already been indicated, Polish archaeology has never conducted field research on such a scale, so there was a lack of various experiences both in the field of methodology of field work and subsequent development of extracted materials. At the same time, the need for fast, due to the approaching anniversary of the millennium of the Polish state, presentation of research results to wide social circles forced to create hasty synthetic shots based on cursory studies. Unfortunately, to a large extent, these millennium popular science publications are today (apart from reports) the only printed remains of research on the beginnings of the Polish state.

The achievements of the millennium research remained a source of knowledge about early medieval castles and the beginnings of Polish cities for decades. In the light of the experience of those years, the early medieval Slavic city was seen as the culmination of the process of socio-economic and political changes that have been taking place for centuries in Central and Eastern Europe. Townforming factors themselves were described as diverse, although craft belief, market and trade development, political and cultural conditions were decisive. These earliest phases of early urban 
organisms were given the name 'city germs', and their origins were referred to the tribal period, most often to the end of the 8th or 9th century. Along with the progress of research, in particular the wider use of dendrochronological dating methods for the purposes of, in the 1990s, there was a critical reevaluation of many of these findings [Buko, 2005, p. 205-208].

\section{REFERENCES}

Buko, A. (2005). Archeologia Polski wczesnośredniowiecznej, Odkrycia - hipotezy - interpretacje. Warszawa.

Dymaczewski, A. (1961). Badania wykopaliskowe w ogrodzie przy ul. Wieżowej 2-4 w Poznaniu w latach 1939, 1950-1953. In: W. Hensel (Ed.), Poznań we wczesnym średniowieczu, 3 (pp. 139-228). WrocławWarszawa: Zakład Narodowy im. Ossolińskich.

Dymaczewski, A., \& Leciejewicz, L. (1955). Osadnictwo wczesnośredniowieczne w południowej części Ostrowa Tumskiego w Poznaniu. Przegląd Zachodni, 11(1-2), 357-376.

Hensel, W. (1949). Tymczasowe wyniki prac wykopaliskowych na Ostrowie Tumskim w Poznaniu w 1948 r. Przegląd Zachodni, 5(3/4), 257-260.

Hensel, W. (1949a). Uwagi o badaniu stanowisk wielowarstwowych. Zeszyty Prehistoryczne Polskiego Towarzystwa Prehistorycznego, 2. Poznań.

Hensel, W. (1952). Odkrycia archeologiczne w Poznaniu w 1952 r. Przegląd Zachodni, 8(11/12), 401404.

Hensel, W. (1953). Poznań w starożytności i we wczesnym średniowieczu. Przegląd Zachodni, 9(6-8), $14-100$.

Hensel, W. (1958). Poznań w zaraniu dziejów od paleolitu do połowy XIII wieku n. e. Wrocław: Zakład Narodowy im. Ossolińskich.

Hensel, W. (1959). Przedmowa. In: W. Hensel (Ed.), Poznań we wczesnym średniowieczu, 1 (pp. 7-12). Warszawa-Wrocław: Zakład Narodowy im. Ossolińskich.

Hensel, W. (1960). Najdawniejsze stolice Polski. Gniezno - Poznań - Kruszwica. Warszawa: Państwowe Wydawnictwo Naukowe.

Hensel, W., \& Żak, J. (1964). Poznań im frühen Mittelalter. Archaeologia Polona, 7, 258-276.

Hołubowicz, W. (1948). Studia nad metodami badań warstw kulturowych w prehistorii polskiej. Toruń.

Jażdżewski, K. (1948-1949). Uwagi nad sposobami pracy wykopaliskowej (w związku z pracą W. Hołubowicza pt. Studia nad metodami badań warstw kulturowych $\mathrm{w}$ prehistorii polskiej). Przegląd Archeologiczny, 8, 96-106.

Kaczmarek, J. (2008). Archeologia miasta Poznania, 1(Stan badań i materiały, Part 1-2). Poznań: Muzeum Archeologiczne w Poznaniu.

Kostrzewski, J. (1938). Zachowajmy na wieki gród Mieszka i Bolesława. Kurier Poznański, 33(402), 18.

Kóčka-Krenz, H. (2001). Zespół pałacowo - sakralny na grodzie poznańskim. In: S. Skibiński (Ed.), Polska na przełomie I i II tysiącleci Materiały Sesji Stowarzyszenia Historyków Sztuki, Poznań, listopad 2000 (pp. 287-296). Poznań: Stowarzyszenie Historyków Sztuki.

Kóčka-Krenz, H. (2004). Ostrów Tumski we wczesnym średniowieczu. In: L. Wilczyński (Ed.), Ostrów Tumski - kolebka Poznania, materiały z sesji naukowej, Poznań, 4 listopada 2003 roku (pp. 21-38). Poznań: Wydawnictwo "Rys".

Kóčka-Krenz, H. (2005). Rezydencja pierwszych Piastów na poznańskim grodzie. In: H. Kóčka-Krenz (Ed.), Poznań we wczesnym średniowieczu, 5 (pp. 59-81). Poznań: Wydawnictwo Poznańskie.

Kócka, W., \& Ostrowska, E. (1954). Uwagi do zagadnienia metodyki wykopalisk. Zapiski Archeologiczne,

Niesiołowska, A., Perzyńska, M., \& Żak, J. (1960). Badania na posesji Ostrów Tumski 13 w latach 1950 1953. In: W. Hensel (Ed.), Poznań we wczesnym średniowieczu, 2 (pp. 67-219). Wrocław-Warszawa: Zakład Narodowy im. Ossolińskich.

Malinowska, M. (1961). Badania na stanowisku Ostrów Tumski 17 w Poznaniu w latach 1953-1954. In: W. Hensel (Ed.), Poznań we wczesnym średniowieczu, 3 (pp. 7-95). Wrocław-Warszawa: Zakład Narodowy im. Ossolińskich. 
Münch, H. (1946). Geneza i rozplanowane miast wielkopolskich XIII i XIV wieku. Kraków: Polska Akademia Umiejętności.

Noszczak, B. (2002). "Sacrum” czy "profanum"? Spór o istotę obchodów Milenium polskiego (19491966). Warszawa: Towarzystwo Naukowe Warszawskie.

Szczerba, A. (2017). Powołanie Kierownictwa Badań nad Początkami Państwa Polskiego. Przegląd Archeologiczny, 65, 13-18.

Wiślański, T. (1960). Badania wykopaliskowe w Poznaniu na posesji Ostrów Tumski 11 w roku 1948. In: W. Hensel (Ed.), Poznań we wczesnym średniowieczu, 2 (pp. 7-65). Wrocław-Warszawa: Zakład Narodowy im. Ossolińskich.

Żak, J. (1959). Badania w ogrodzie przy ul. Ostrów Tumski 10 w 1946 r. In: W. Hensel (Ed.), Poznań we wczesnym średniowieczu, 1 (pp. 81-129). Warszawa-Wrocław: Zakład Narodowy im. Ossolińskich.

Żurowski, T. (1947). Pomiar w technice wykopaliskowej. Z Otchłani Wieków, 16, 136-141.

Żurowski, T. (1948). Błędne pomiary w technice wykopaliskowej. Z Otchłani Wieków, 17, 76-80.

Żurowski, T. (1951). Cechy warstw kulturowych. Z Otchłani Wieków, 20, 101-104.

Стаття: надійшла до редакції 10.07.2019

прийнята до друку 29.10.2019

\section{МІСЬКА АРХЕОЛОГІЯ У ДІЯЛЬНОСТІ УПРАВЛІННЯ ДОСЛІДЖЕНЬ ПРО ПОЧАТКИ ПОЛЬСЬКОЇ ДЕРЖАВИ (1949-1953)}

Адріана ЩЕРБА

Інститут археології Лодзького університету,

вул. Нарутовича, 65, 91-145, м. Лодзь, Польща, e-mail: Adrianna.Szczerba@uni.lodz.pl

Управління дослідженнями про початки Польської держави засноване з метою проведення широких міждисциплінарних студій генези та функціонування держави часів перших П’ястів. Ці роботи приурочено до 1000-літнього ювілею заснування та хрещення Польської держави. У 1949-1953 рр. на території 31 населеного пункту проведено дослідження ранньосередньовічних пам'яток. Особливу увагу звернено на укріплені міста, з яким пов'язана історія династії П’ястів (Гданськ, Гнєзно, Геч, Познань, Крушвиця, Каліш, Тум (Ленчицький повіт), Блонє, Брудно, Вроцлав, Ополе Немча, Цешин та Віслиця). Більшість з них розташовані в історичних центрах сучасних міст. Із цієї ситуації закономірно випливає поєднання проблем вивчення ранньосередньовічних замків та заснування польських міст. Ранньосередньовічні пам'ятки на території Польщі часто мають складну стратиграфію, особливо це стосується міст та фортець, що є непростими для розкопок. Також відзначимо, що до Другої Світової війни вчені мали дуже незначний досвід дослідження багатошарових пам'яток, i, як наслідок, методи вивчення великих поселенських комплексів розвивались та вдосконалювались у процесі самих досліджень. Отже програма археології Тисячоліття стала своєрідним тестовим полігоном для розробки методики міської археології на території Польщі.

Ключові слова: історія Польської археології, Управління дослідженнями про початки Польської держави, археологія Тисячоліття, міська археологія. 